\title{
Emerging Roles of Extracellular Vesicles in the Nervous System
}

\author{
Lawrence Rajendran, ${ }^{1,2}$ Jitin Bali, ${ }^{1,2}$ @Maureen M. Barr, ${ }^{3}$ Felipe A. Court, ${ }^{4,5}$ Eva-Maria Krämer-Albers, ${ }^{6}$ Frederic Picou, ${ }^{4}$ \\ Graça Raposo, ${ }^{7,8}$ Kristan E. van der Vos, ${ }^{9}$ Guillaume van Niel, ${ }^{7,8}$ Juan Wang, ${ }^{3}$ and $\odot$ Xandra O. Breakefield ${ }^{10}$ \\ ${ }^{1}$ Systems and Cell Biology of Neurodegeneration, Division of Psychiatry Research and ${ }^{2}$ Graduate Schools of Zurich Neuroscience Center and Integrative \\ Physiology, University of Zurich, 8006 Zurich, Switzerland, ${ }^{3}$ Human Genetics Institute, Department of Genetics, Rutgers University, Piscataway, New Jersey \\ 08854, ${ }^{4}$ Millenium Nucleus for Regenerative Biology, Faculty of Biology, Pontificia Universidad Catolica de Chile, Santiago, Chile, ${ }^{5}$ Neurounion Biomedical \\ Foundation, Santiago, Chile, ${ }^{D}$ Department of Molecular Cell Biology, and Focus Programme of Translational Neuroscience, University of Mainz, 55122 \\ Mainz, Germany, ${ }^{7}$ Institut Curie, Centre de Recherche, F-75248 Paris, France, ${ }^{8}$ Structure and Membrane Compartments, Centre National de la Recherche \\ Scientifique, Unité Mixte de Recherche 144, Paris F-75248, France, ${ }^{9}$ Division of Molecular Carcinogenesis, The Netherlands Cancer Institute, Amsterdam, \\ The Netherlands, and ${ }^{10}$ Departments of Neurology and Radiology, Massachusetts General Hospital and Program in Neuroscience, Harvard Medical School, \\ Boston, Massachusetts 02114
}

Information exchange executed by extracellular vesicles, including exosomes, is a newly described form of intercellular communication important in the development and physiology of neural systems. These vesicles can be released from cells, are packed with information including signaling proteins and both coding and regulatory RNAs, and can be taken up by target cells, thereby facilitating the transfer of multilevel information. Recent studies demonstrate their critical role in physiological processes, including nerve regeneration, synaptic function, and behavior. These vesicles also have a sinister role in the propagation of toxic amyloid proteins in neurodegenerative conditions, including prion diseases and Alzheimer's and Parkinson's diseases, in inducing neuroinflammation by exchange of information between the neurons and glia, as well as in aiding tumor progression in the brain by subversion of normal cells. This article provides a summary of topics covered in a symposium and is not meant to be a comprehensive review of the subject.

\section{Introduction}

This mini-symposium focuses on the role of extracellular vesicles (EVs) in four contexts that are important in understanding intercellular communication in neural systems: sensory behavior, synaptic communication, nerve regeneration, neurodegeneration, and brain tumors. The focus is on mechanisms of information transfer through EVs, how this process is unique compared with other forms of intercellular communication, and how this information can alter cellular phenotypes. This article summarizes

\section{Received Aug. 6, 2014; revised 0ct. 8, 2014; accepted 0ct. 8, 2014}

L.R. was supported by the Velux Foundation Professorship Grant, the interdisciplinary Swiss National Science Foundation Grant SNF-CR3313-153039, the SCOPES Grant IZ73Z0_152496, the Novartis Foundation Grant, Bangerter Stiftung, and the Synapsis Foundation. M.M.B. and J.W. were supported by National Institutes of Health Grants R01DK059418 and R01DK074746. F.A.C. and F.P. were supported by Grants from Fondo Nacional de Desarrollo Científico y Tecnológico Grants 1110987 and 3130527, Millennium Nucleus RC-120003, and Ring Initiative ACT1109. E.-M.K.-A. was supported by Deutsche Forschungsgemeinschaft research Grants KR 3668/1-1 and DFG SPP1757 (KR-3668/2-1). K.E.v.d.V. was supported by the Dutch Scientific Organisation (NWO-Rubicon). G.v.N. and G.R. were supported by Research Grants from the Amyloidosis Foundation and the Fondation pour la Recherche Medicale. X.O.B. was supported by National Institutes of Health/National Cancer Institute Grants P01 CA069246, CA141150, and U19 CA179563 through the National Institutes of Health Common Fund, the Office of Strategic Coordination/Office of the National Institutes of Health Director. We thank Ms. Suzanne McDavitt for skilled editorial assistance.

The authors declare no competing financial interests.

Correspondence should be addressed to either of the following: Dr. Xandra 0. Breakefield, Molecular Neurogenetics Unit, Massachusetts General Hospital-East, 13th Street, Building 149, Charlestown, MA 02129, E-mail: breakefield@hms.harvard.edu; or Dr. Lawrence Rajendran, Systems and Cell Biology of Neurodegeneration, Division of Psychiatry Research, University of Zurich, Wagistrasse 12, Schlieren, Switzerland. E-mail: Rajendran@bli.uzh.ch. DOI:10.1523/JNEUROSCI.3258-14.2014

Copyright $\odot 2014$ the authors $\quad 0270-6474 / 14 / 3415482-08 \$ 15.00 / 0$ topics covered in a mini-symposium. For comprehensive review of the subject, the reader is referred to several other reviews on this topic (Aguzzi and Rajendran, 2009; van der Vos et al., 2011; Lai and Breakefield, 2012; Lopez-Verrilli and Court, 2013a).

EVs are released by essentially all cells in the nervous system during normal development, physiologic homeostasis, and response to pathogenic conditions. Their composition varies with respect to cell of origin and physiologic conditions, and they have a pivotal role in phenotypic responses and fate of cells, including neurons and glia. This is a new area of research in which neuroscientists need to acquire more basic information and explore whether this form of intercellular communication is critical in neural functions and whether it can be exploited for diagnosis and therapy of neural disorders. Interestingly, EVs also have potential use as biomarkers of physiologic and disease states (Rak, 2013; Hochberg et al., 2014; Redzic et al., 2014a, b), as well as being harnessed as therapeutic delivery vehicles (El Andaloussi et al., 2013; György et al., 2014).

\section{Ciliary EVs mediate communication between animals}

Cilia are microtubule-based organelles that protrude into the extracellular space from most mammalian cells and play important roles in human development and health, with defects in cilia resulting in human syndromes called ciliopathies (Yuan and Sun, 2013). Cilia act as cellular antennae. In Chlamydomonas, Caenorhabditis elegans, and mammals, EVs are closely associated with cilia, suggesting that cilia may be essential in EV-mediated com- 

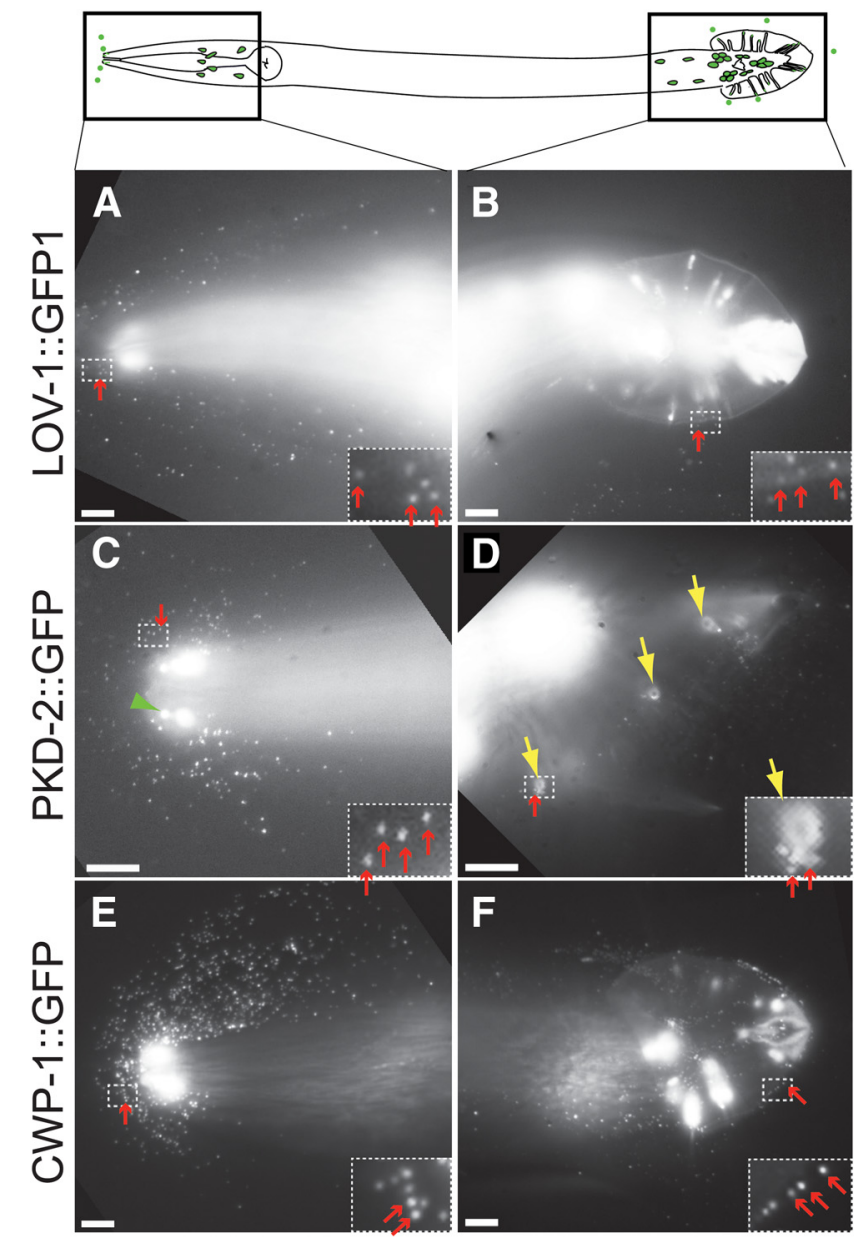

control

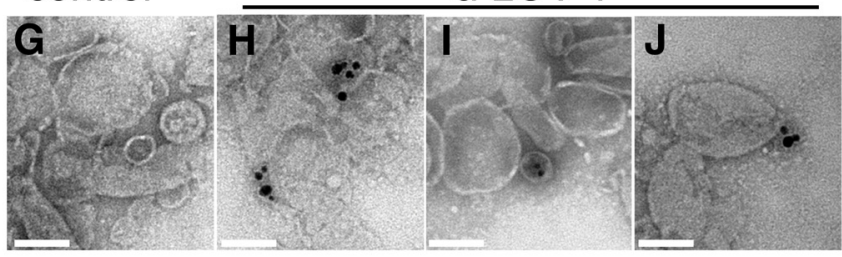

K

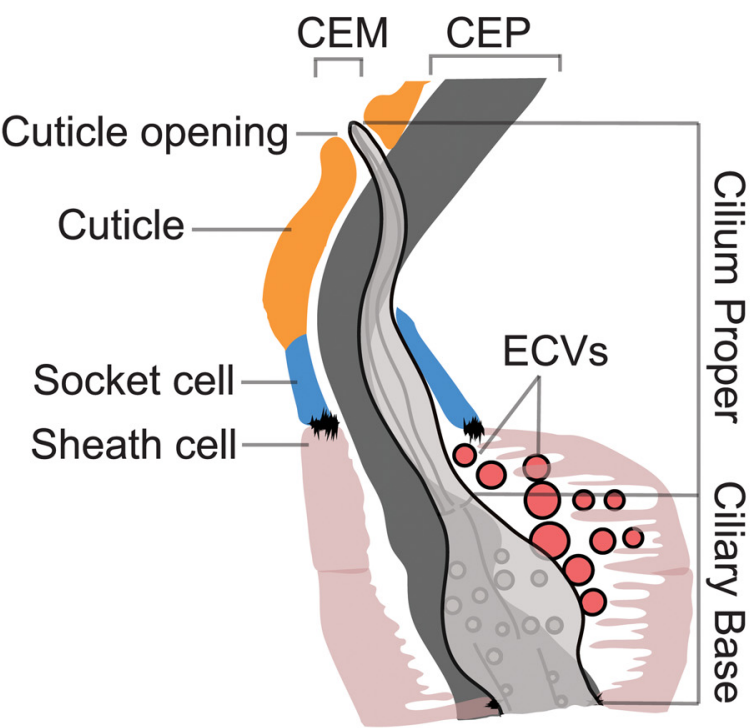

Figure 1. IL2 and male-specific B-type ciliated neurons release GFP-labeled EVs. Top panel, Diagram of six IL2 and 21 B-type sensory neurons in adult C. elegans male (in the head, four CEM neurons, and in the tail, one HOB and 16 RnB neurons). $\boldsymbol{A}, \boldsymbol{B}$, Male head and tail images of C. elegans polycystin-1 LOV-1::GFP reporter [N-terminal extracellular domain of LOV-1 (1-991 aa) fused to GFP]. In $\boldsymbol{A}-\boldsymbol{F}$, red arrows point to EVs surrounding the head and the tail. Insets, Framed area zoomed to $4 \times$, and increased brightness to show GFP-labeled EVs. C, D, Male head and tail images of C. elegans polycystin-2 PKD-2::GFP reporter. Green arrowhead points to a CEM cilium with PKD-2::GFP enriched at the tip. Yellow arrows point to the cuticular pore of the ray neurons and PKD-2::GFP release around the pore. E, $F$, Coexpressed with polycystin protein CWP-1::GFP release from the head and the tail. G-J, Negatively stained EVs. G, EVs with no primary antibody control. $\boldsymbol{H}, \boldsymbol{I}, \boldsymbol{J}$, Different images of LOV-1 antibody labeling endogenous LOV-1 on EVs purified from wild-type adult animals, detection by $0.8 \mathrm{~nm}$ ultrasmall gold, followed by silver enhancement. Scale bars: $\boldsymbol{A}-\boldsymbol{F}, 10 \mu \mathrm{m} ; \boldsymbol{G}-\boldsymbol{J}, 100 \mathrm{~nm}$. $\boldsymbol{K}$, Model based on electron tomography of the distal end of the CEM neuron and its surroundings. The glial sheath cell and socket cell form a continuous lumen surrounding the CEM neuron cilium, which is exposed to the environment directly through a cuticular opening. The lumen is shared by CEM and CEP neurons. The CEM neuron is more centrally located in the lumen, while the CEP neuron is closer to the side of the lumen. EVs are observed in the cephalic lumen. Reproduced from Wang et al. (2014).

munication as both senders and receivers (Tanaka et al., 2005; Hogan et al., 2009; Masyuk et al., 2010; Bakeberg et al., 2011; Pampliega et al., 2013; Wood et al., 2013; Wang et al., 2014).

C. elegans-ciliated sensory neurons shed and release transient receptor potential polycystin-containing EVs that regulate animal-to-animal communication (Fig. 1) (Wang et al., 2014). EVs isolated from wild-type C. elegans do not act as longrange chemoattractants but do promote changes in $C$. elegans male locomotory behaviors and male-specific tail chasing behavior. EVs lacking transient receptor potential polycystin-2 fail to trigger tail chasing. These results show that environmentally released EVs and EV-cargo composition modulate animal behaviors, which is a novel function for EVs. Wang et al. (2014) propose that EVs play broad and important, as yet unexplored roles, in communication and behavior in the animal kingdom.

In humans, the polycystin-encoding genes PKD1 and PKD2 are needed for kidney function; loss of polycystin function leads to autosomal dominant polycystic kidney disease (frequency: 1 in 400 to 1 in 1000), one of the most common monogenic diseases (Harris and Torres, 2014). In C. elegans and mammals, polycystin-1 (an 11 transmembrane spanning receptor) and polycystin-2 (a transient receptor potential channel) act in the same genetic pathway, serve in a sensory capacity, localize to cilia, and are contained in secreted EVs released from cilia (Hogan et al., 2009; O'Hagan et al., 2014; Semmo et al., 2014; Wang et al., 2014), indicating ancient conserved functions. The M.M.B. group propose that defects in ciliary EV biogenesis, release, or signaling may contribute to pathogenesis of ciliary diseases, such as autosomal dominant polycystic kidney disease, and are using the worm as a model to study the fundamental biology of EVs.

In summary, C. elegans is a transparent, multicellular animal that releases GFP-tagged EVs from ciliated sensory neurons (Fig. 1), features that enable subcellular imaging in living animals. EV detection is a challenge and obstacle because of their small size. The M.M.B. laboratory has developed a system to visualize and monitor EV dynamics and functions in a living animal and in real time. To define the properties of an EV-releasing neuron and to decipher the biology of ciliary-released, polycystin-containing EVs, they have applied a state-of-the-art technique (Kaletsky et al., unpublished observations) to isolate and profile adult EV- 


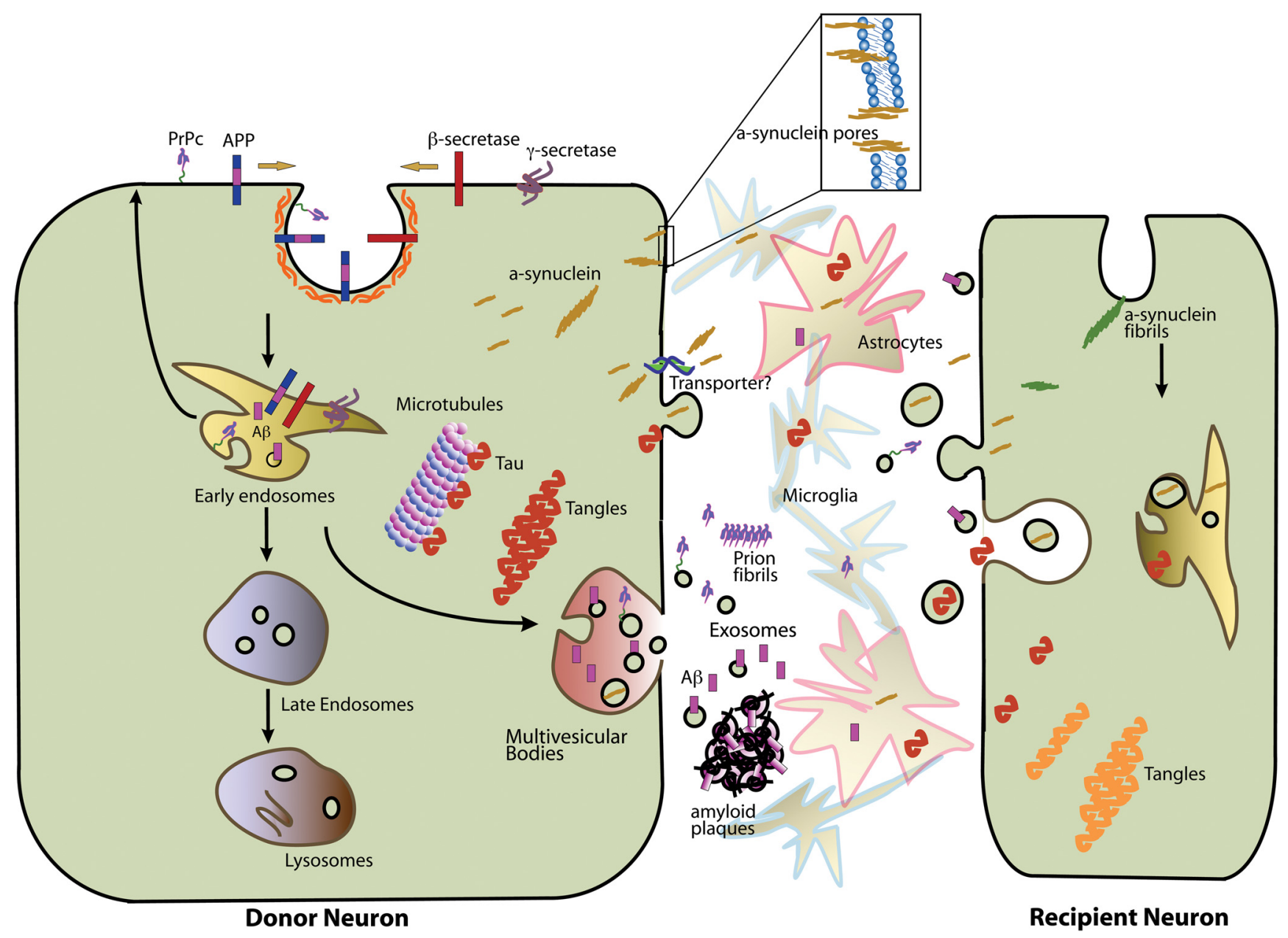

Figure 2. Diagrammatic representation of the role of EVs in the release and uptake of amyloid proteins. Here PrPc, $A \beta$, Tau, and $\alpha$-synuclein are shown as disease-related amyloid proteins. $A \beta$ is derived from the proteolytic processing of the APP in early endosomes and is then retrogradely transported to MVBs. Once released in association with exosomes from the donor neurons, these proteins can be taken up in the recipient cells either via endocytosis or by direct penetration. Astrocytes and microglia might aid in the transmissibility. Adapted from Aguzzi and Rajendran (2009).

releasing neurons and identified 295 signature genes (Wang et al., unpublished observations). This signature gene dataset and forward genetic screens have the potential to identify pathways important for EV biogenesis, release, and/or signaling.

\section{Delivery on call: neurotransmitter-triggered transfer of exosomes from oligodendrocytes to neurons}

The role of neuronal EVs is not just limited to release of functionally relevant molecules but also to their ability to collaborate with other cells in the brain (i.e., microglia). The relevance of neuron-glia communication for the developing as well as the adult nervous system is becoming more and more apparent. CNS astrocytes, oligodendrocytes, microglia, and peripheral nervous system Schwann cells (SCs) execute versatile functions that influence neuronal performance and brain output. Oligodendrocytes not only myelinate axons but also provide support to maintain long-term axonal integrity (Nave, 2010). Recent work demonstrated that EVs with the characteristics of exosomes participate in reciprocal oligodendrocyte-neuron communication and deliver cargo from oligodendrocytes to neurons (Frühbeis et al., 2013a, b). Indeed, multivesicular bodies (MVBs) localize to the adaxonal cytoplasmic compartment (nearest the myelin sheath) of myelinating oligodendrocytes in situ, suggesting exosome release into the periaxonal space. Oligodendroglial exo- some secretion depends on neuronal electrical activity and is triggered by the neurotransmitter glutamate through activation of glial ionotropic glutamate receptors, in particular NMDA receptors. Liberated exosomes are then internalized by neurons, and the exosomal cargo becomes available to the neuronal metabolism, as evidenced by delivery of an ectopic reporter enzyme activity from oligodendrocytes to neurons. Hence, neurons demand exosomes from glial cells by neurotransmitter signaling and take advantage of glia-derived cargo.

But do the receiving neurons actually benefit from exosome transfer? The cargo delivered by exosomes includes a number of enzymes with metabolic functions, including catalase and superoxide dismutase-1, which can help neurons to resist oxidative stress. Consistently, neurons exposed to oxidative stress or other harmful conditions survived better if they had received oligodendroglial exosomes, suggesting that exosomes are protective and increase the neuronal stress tolerance (Frühbeis et al., 2013b; Fröhlich et al., 2014). Oligodendroglial exosomes elicit a number of physiological responses in target neurons. Electrophysiological analysis of cultured neurons using multielectrode arrays indicated that the action potential firing rate is increased in response to these exosomes. Furthermore, a number of signaling pathways, including the AKT and ERK pathways, appear activated, 


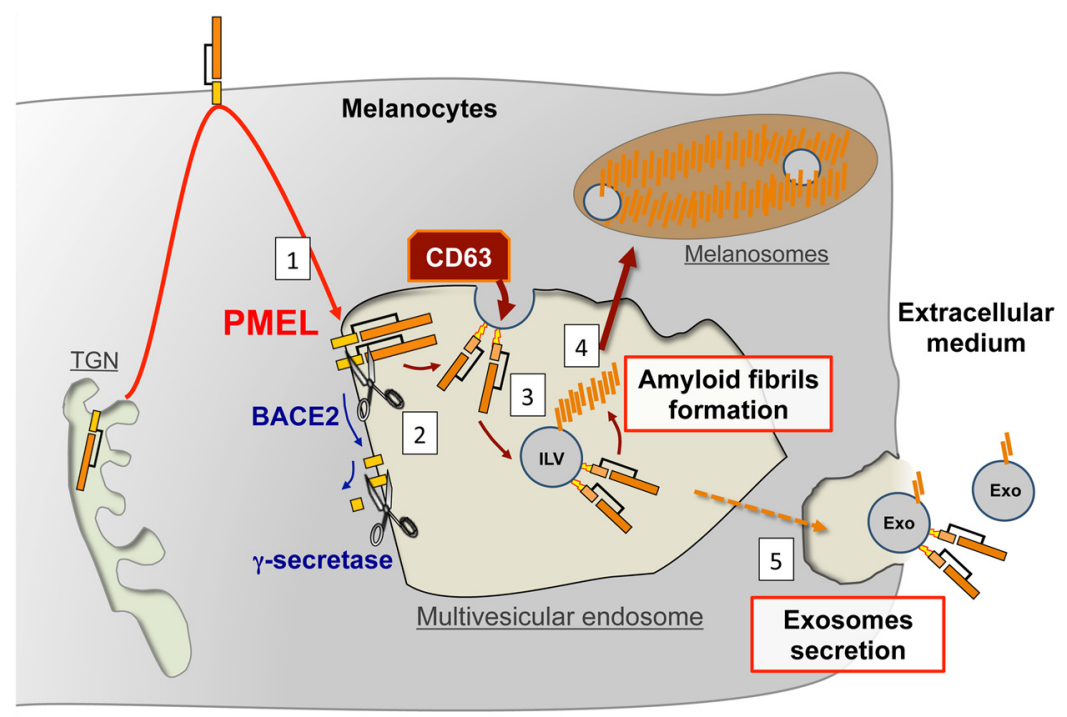

Figure 3. Schematic representation of PMEL-derived amyloidogenesis. Within pigment cells, such as melanocytes, PMEL reaches MVEs from the plasma membrane (1). At the limiting membrane of the compartment, the PMEL luminal domain is released by BACE2 from its (-terminal fragment that is further cleaved by $\gamma$-secretase (2). The luminal domain of PMEL is sorted to ILVs by an unconventional sorting mechanism regulated by $\operatorname{CD} 63$ (3). At the surface of ILVs, PMEL domains aggregate into amyloid fibrils that accumulate in melanosomes (4). The fraction of ILVs that is secreted as exosomes in the extracellular medium is currently under investigation to better understand the formation of amyloid fibrils at their surface (5).

and the gene expression pattern is modified in neurons that received exosomes (Fröhlich et al., 2014).

Axon death is a major problem in most demyelinating diseases; however, the underlying mechanisms are not well understood. An evident question is whether glia-to-neuron exosome transfer might play a specific role in glial support and long-term maintenance of axons. The role of oligodendrocytes in glial support was discovered in mice lacking glial genes, such as $P l p 1$ or Cnp, which suffer from secondary axonal degeneration. Oligodendroglial exosomes carry the products of both of these genes (mRNA as well as protein), indicating a possible functional link between abnormal exosome function and axonal degeneration in these mice. A differential analysis of exosomes derived from wildtype and knock-out oligodendrocytes as well as their specific impact on target neurons will further illuminate this exciting topic.

In conclusion, oligodendroglial exosomes function as vehicles for the transfer of biomolecules from oligodendrocytes to neurons and play a potential role in neuroprotection mediated by glial support. Target neurons appear to control exosome availability by means of their own activity, implementing a mode of "delivery on call."

\section{Vesicular transfer from glia to neurons during regeneration}

Nervous system function relies on the coordinated action of neurons and glial cells. In recent years, the importance of glial cells for several aspects of nervous system function has been underscored. Phenomena, such as synaptic activity, conduction of action potentials, neuronal growth, and regeneration, to name a few, are fine-tuned by glial cells. We have proposed a model in which the axon has certain autonomy from the neuronal cell body, and its associated glial cell is a major regulator of local axonal programs, including a regenerative program of axonal extension (Court and Alvarez, 2005), a destruction program activated by various stimuli (Barrientos et al., 2011; Villegas et al., 2014), and local protein synthesis in the axon (Court et al., 2008). Several intercellular mechanisms have been shown to operate on a local basis in the neuron-glia unit, including contactmediated signaling and extracellular free ligands. Recently, another regulatory mechanism has emerged in which a cell releases vesicles containing RNAs and proteins that are taken up and incorporated into the target recipient cell (Simons and Raposo, 2009). Vesicular-mediated transfer of molecular cargoes between glial cells and neurons has been described in the nervous system (Lopez-Verrilli and Court, 2012, 2013a). We have demonstrated vesicular-mediated transfer of ribosomes from SCs, the peripheral glial cell type, to axons in vivo after axonal damage as well as during axonal regeneration (Court et al., 2008, 2011). Recently, we found that exosomes secreted by SCs and selectively internalized by axons increase neurite growth substantially and greatly enhance axonal regeneration in vitro and in vivo (Lopez-Verrilli et al., 2013b). The F.A.C. laboratory is now using a combination of next-generation sequencing, proteomics, and bioinformatic analysis to identify RNAs and proteins present in SC exosomes, and searching for candidates mediating the functional effect of SC exosomes on axonal regeneration. Preliminary analysis demonstrates that mRNA and miRNA are selectively loaded into SC exosomes, and some of the mRNA present in these exosomes encode neuronal-specific proteins. In addition, SC exosomes trigger a broad change in the transcriptional profile of recipient neurons, revealing novel growth-associated pathways triggered by these vesicles. This mode of interaction provides a new dimension to the understanding of the intercellular regulation at large, with the prediction that a number of phenomena of the nervous system, which are still poorly understood, will be revealed under this new light.

\section{Role of exosomes in Alzheimer's disease (AD)}

In addition to having crucial roles in physiological processes, such as neuronal development, repair, and synaptic function, EVs/exosomes also contribute to the development of disease states. Neurodegenerative diseases, including AD, Parkinson's disease, and prion diseases, are characterized by protein aggregation and deposition in specific brain regions (Bellingham et al., $2012 b$ ). Although the exact pathological significance of these aggregates remains to be conclusively resolved, the biology behind their formation is fascinating but remains largely elusive. Recent findings, on the release and spread of several amyloid-forming proteins, suggest a model where these proteins are released from affected cells in the form of amyloid seeds and then enter other cells and aid in the spread of the disease. This poses several questions. How are these aggregates released from the cells? Once released, how do they form plaques and propagate in the aqueous extracellular space to gain access to host counterparts? We propose that exosomes, defined as endocytically derived nanovesicles, are a major vehicle that shuttles amyloids out of the cell and participates in plaque formation. The L.R. group provides evidence that amyloids involved in $\mathrm{AD}$, such as amyloid $\beta(\mathrm{A} \beta)$, are released via exosomes and that exosome-associated amyloids can act as seeds for plaque formation. $\mathrm{A} \beta$ is generated by proteo- 


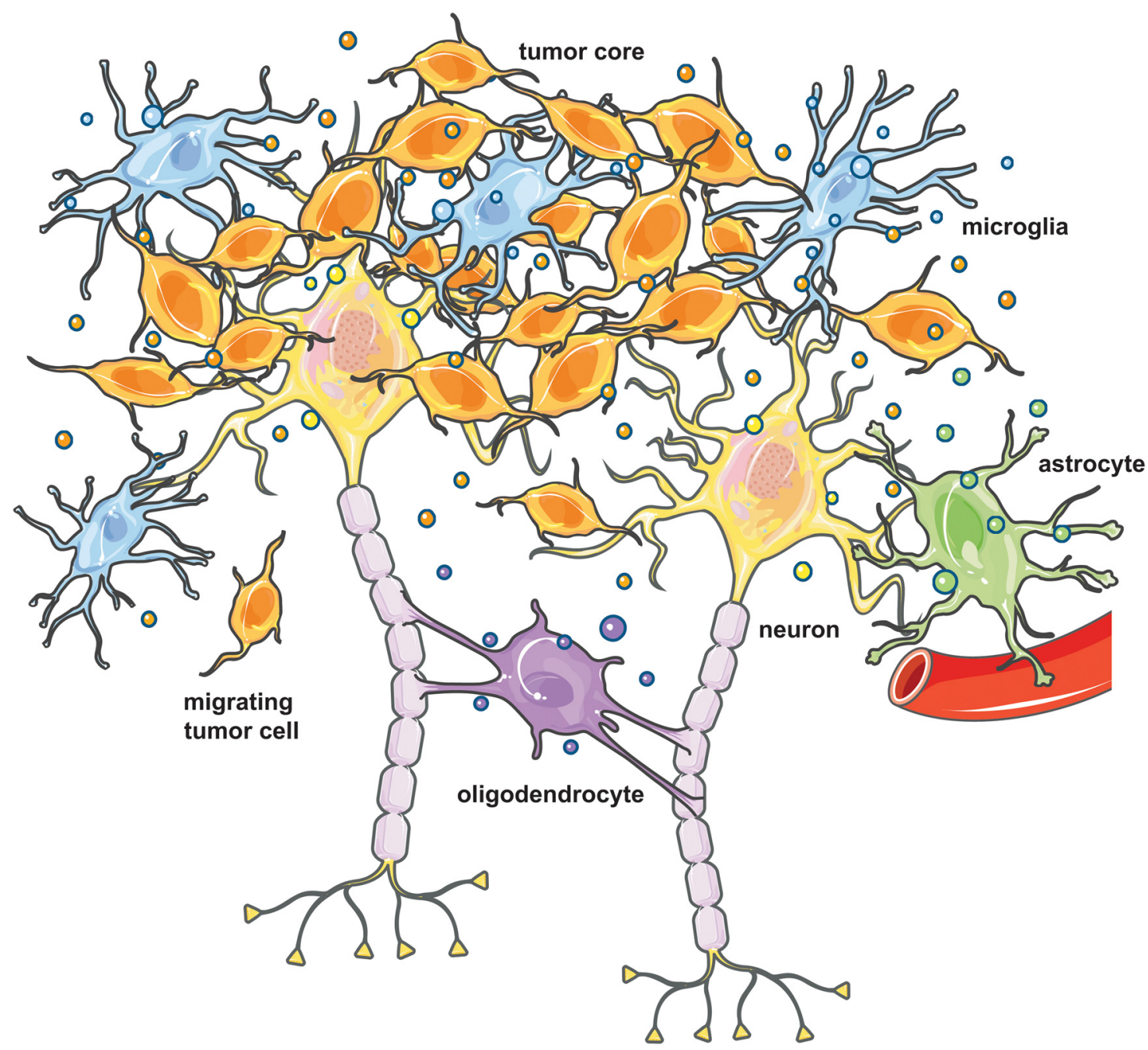

Figure 4. The GBM tumor microenvironment. Glioblastoma cells grow interspersed within the normal brain parenchyma. The tumor cells interact with multiple different cell types, including astrocytes, neurons, oligodendrocytes, and microglia. Release of tumor-derived EVs alters the phenotype and transcriptome of recipient cells and enables the creation of a tumor-promoting environment. Normal cells also release vesicles, and their content may change in the context of the tumor. This figure was produced using Servier Medical Art (http://www.servier.com).

lytic processing of the amyloid precursor protein (APP) substrate by $\beta$ - and $\gamma$-secretases. APP, BACE1 ( $\beta$-secretase), and the $\gamma$-secretase complex components are all transmembrane proteins, and endocytosis is involved in $\mathrm{A} \beta$ production (Koo and Squazzo, 1994; Ehehalt et al., 2003; Grbovic et al., 2003; Rajendran et al., 2006, 2008). APP processing by BACE1 and $\gamma$-secretase to generate $A \beta$ occurs in early endosomes. Furthermore, the L.R. laboratory showed that preclustering of APP in a cholesterol- and flotillin-dependent manner is essential for its internalization via a specialized clathrin-dependent endocytic pathway (Schneider et al., 2008). Then how is the endosomally generated $\mathrm{A} \beta$ released out of the cell? Proteins that are destined for lysosomal degradation are sorted from the early endosomes to intraluminal vesicles (ILVs) of late endosomes (Théry et al., 2009; Bobrie et al., 2011) or to MVBs. MVBs have the ability to fuse with the plasma membrane to release the ILVs as exosomes (Stoorvogel et al., 2002). Because $A \beta$ is generated in early endosomes in the endocytic route and found in MVBs, fusion of these MVBs with the plasma membrane may serve as a means of release of $A \beta$ complexed with exosomes. To test this hypothesis, the L.R. laboratory found that a small fraction of extracellular $\mathrm{A} \beta$ was indeed associated with exosomes. Immunoelectron microscopy of exosomes showed that $\mathrm{A} \beta$ peptides not only cofractionated with exosomes but were also physically associated with them. To investigate whether these findings have any bearing on Alzheimer pathology, immunohistochemistry analysis was performed with antibodies against exosomal proteins on brain sections from $\mathrm{AD}$ patients and age-matched control subjects. Enrichment of Alix, a marker for exosomes, was seen around small neuritic plaques and a moderate signal in large diffuse plaques in brain sections from all $\mathrm{AD}$ patients tested. Alix staining was largely absent in brain sections of control subjects. Similar to $\mathrm{A} \beta$, both Tau and $\alpha$-synuclein are also found in EVs; together, this represents a novel mode of amyloid transmissibility (Fig. 2) (Aguzzi and Rajendran, 2009).

\section{Study of exosomes sheds new light on physiological amyloidogenesis}

Exosomes correspond to the ILVs of multivesicular endosomes (MVEs or MVBs). In this context, their study can be very informative as for their role in MVEs. Among the several cellular processes involved in pathological amyloid formation, amyloidogenesis, there is an increasing amount of evidence for the involvement of the endosomal system and, in particular, of MVEs in its initiation (Takahashi et al., 2002). Within MVEs, ILVs are thought to serve as processing platforms favoring amy- 
loidogenic conversion of APP (Rajendran et al., 2006; Vella et al., 2008). In the extracellular medium, exosomes would likely be responsible for the transmissible character of amyloidogenic factors through the brain (Aguzzi and Rajendran, 2009). Amyloidogenesis usually refers to the pathological formation of insoluble fibrous aggregates from proteins, such as the APP during AD (Haass and Selkoe, 2007; Greenwald and Riek, 2010). Our work proposes an innovative approach to investigate the interplay between amyloidogenesis and MVEs by using a nonpathological amyloidogenesis process occurring in pigment cells. These cells have tuned MVEs to produce amyloid fibrils in a physiological and safe manner (Watt et al., 2013). Interestingly, this model presents pertinent analogies with amyloidogenesis associated with $\mathrm{AD}$ (Hammer et al., 2008), as amyloid fibrils produced during $\mathrm{AD}$ and in melanocytes have similar biophysical and biochemical properties (Fowler et al., 2006). These functional amyloids are derived from the premelanosome protein (PMEL) that shares several analogies with APP in terms of intracellular trafficking and processing (Kummer et al., 2009; van Niel et al., 2011; Rajendran and Annaert, 2012; Rochin et al., 2013).

PMEL-derived amyloids are produced by melanocytes and retinal pigmented epithelium that are able to produce the melanin pigment in the skin, the hair, and the eyes (Theos et al., 2005). Melanogenesis is initiated in MVEs that mature into lysosomerelated organelles called melanosomes (Raposo and Marks, 2007). Within MVEs, the luminal fragment of PMEL aggregates into amyloid fibrils (Hurbain et al., 2008), which further serves as a structural scaffold for melanin deposit (Raposo and Marks, 2007). The G.R. laboratory and others have evidence that the formation of PMEL-derived fibrils results from a complex and tightly regulated cooperation between cleavage and sorting processes of PMEL. The cleavage of PMEL by BACE-2 (Rochin et al., 2013) releases its luminal amyloidogenic fragment from a C-terminal fragment that is further cleaved by $\gamma$-secretase complex (Kummer et al., 2009; van Niel et al., 2011). Concomitantly to its processing, PMEL-derived amyloid fibril formation requires the sorting of PMEL luminal domain on ILVs by unconventional sorting mechanisms involving the tetraspanin CD63 (Theos et al., 2006; van Niel et al., 2011) (Fig. 3). Threedimensional reconstruction of melanosomes by electron tomography (Hurbain et al., 2008) supports the hypothesis that ILVs can serve as nucleating platforms for amyloids within MVEs. To investigate the formation of amyloids at the surface of ILVs, our group has exploited cryo-electron microscopy to image at nanometric resolution ILVs secreted as exosomes in close to their native state. Their data provide further insight into the role of MVEs and exosomes in functional amyloidogenesis and open new avenues for the understanding of pathological amyloidogenesis.

\section{EVs as tactics in brain tumor invasion}

Glioblastoma cells are known to release a "barrage" of heterogeneous EVs varying in size: from $50 \mathrm{~nm}$ "exosomes" to $1 \mu \mathrm{m}$ "oncosomes" containing a distinct set of proteins, lipids, and nucleic acids with respect to the contents of the cell (Skog et al., 2008; Garnier et al., 2013; Redzic et al., 2014b). These vesicles influence surrounding normal cells, including endothelial cells, microglia/macrophages, and immune cells in the brain tumor environment, such that their phenotype changes in support of tumor growth (Fig. 4). Release of tumor vesicles and uptake by normal cells are associated with progression, angiogenesis, tumor cell invasion, and suppression of immune responses to the tumor (Iero et al., 2008; D'Asti et al., 2012; Vader et al., 2014). At the same time, these normal cells also release EVs taken up by the tumor cells, with their function still under study.

Our group has focused on the nucleic content of these tumor vesicles to understand their potential role in this "transformation" of the brain tumor environment. RNA within vesicles is quite stable and allows for transport of this labile nucleic acid across the extracellular milieu and uptake into surrounding cells. Initial studies showed that both the mRNA and miRNA content of EVs isolated from primary human glioblastoma cells in culture was unique, with some RNAs enriched hundreds of fold over that in the tumor cells (Skog et al., 2008). Most of the extracellular RNA in these vesicles is of low molecular weight ( $\sim 200 \mathrm{bp})$, but sequences up to several kilobases can be detected (Balaj et al., 2011). Sequencing of EV RNA by others finds mRNAs, microRNAs (miRs), ribosomal RNA, transfer RNA, lncRNA, piwi-interacting RNA, small nuclear RNA, and small nucleolar RNA (Bellingham et al., 2012a; Nolte-'t Hoen et al., 2012). Interestingly, EVs from some brain tumor cells also contain a high content of retrotransposon sequences and oncogene DNA (Balaj et al., 2011).

A key question is to what extent is the RNA transferred via EVs functional in recipient cells. Not only does the phenotype of cells exposed to glioma EVs change (Skog et al., 2008; Al-Nedawi et al., 2009), but also the transcriptome of these recipient cells is perturbed (Li et al., 2013). Although a reporter mRNA encoding a luciferase transferred from glioma EVs can be translated in recipient cells (Skog et al., 2008; Lai et al., submitted), this mRNA was $<1.0 \mathrm{~kb}$ and other studies indicate that many mRNA transcript in EVs may be fragmented (Batagov and Kurochkin, 2013). Glioblastoma multiforme (GBM) EV transfer of miR-1 has been associated with multiple changes in the cells in the microenvironment that promote tumor growth (Bronisz et al., 2014), but it is difficult to "tease out" the effect of a single miR in the context of the hundreds of other RNAs and proteins also present in those vesicles. The X.O.B. laboratory has found high levels of miR-451 and miR-21 in GBM EVs, which can raise levels in recipient microglia by up to 40 -fold, and this elevation occurs in parallel with increased proliferation, changes in cytokine profiles and skewing toward a tumor-associated phenotype (van der Vos et al., manuscript submitted). Additionally, microglia stimulated with GBMderived EVs show downregulation of a common mRNA target for miR451 and miR21, c-Myc, which occurs both in cell culture and in vivo.

In conclusion, as evidenced by these studies, the role of EVs is emerging and expanding in several areas of neural communication and disease. For example, these vesicles can act as vehicles for intercellular communication involving signals for behavioral phenotypes in nematodes. Their ability to mediate communication between neuron and glia ensures proper signaling at the synapse and in neuronal repair and growth. However, their ability to mediate intercellular transfer also confers on EVs a baleful role in neurodegenerative diseases and progression of brain tumors. In neurodegenerative diseases, they aid in the formation of seeds for toxic amyloid proteins and also may have a role in the dissemination of amyloid proteins within the brain. Because these vesicles can be taken up by cells and release their luminal contents, they can also be engineered to deliver therapeutic agents. Because their composition reflects their cell of origin, they also have the potential to be biomarkers in diagnosis of neural diseases. More research on the biology and physical properties of these vesicles is needed to understand their roles in communication within the nervous system and to deliberate their use in diagnosis and therapy. Exciting times lie ahead for EV research in 
neuroscience, and this symposium reflects this growing interest and sets the stage for further insights.

\section{References}

Aguzzi A, Rajendran L (2009) The transcellular spread of cytosolic amyloids, prions, and prionoids. Neuron 64:783-790. CrossRef Medline

Al-Nedawi K, Meehan B, Rak J (2009) Microvesicles: messengers and mediators of tumor progression. Cell Cycle 8:2014-2018. CrossRef Medline

Bakeberg JL, Tammachote R, Woollard JR, Hogan MC, Tuan HF, Li M, van Deursen JM, Wu Y, Huang BQ, Torres VE, Harris PC, Ward CJ (2011) Epitope-tagged Pkhd1 tracks the processing, secretion, and localization of fibrocystin. J Am Soc Nephrol 22:2266-2277. CrossRef Medline

Balaj L, Lessard R, Dai L, Cho YJ, Pomeroy SL, Breakefield XO, Skog J (2011) Tumour microvesicles contain retrotransposon elements and amplified oncogene sequences. Nat Commun 2:180. CrossRef Medline

Barrientos SA, Martinez NW, Yoo S, Jara JS, Zamorano S, Hetz C, Twiss JL, Alvarez J, Court FA (2011) Axonal degeneration is mediated by the mitochondrial permeability transition pore. J Neurosci 31:966-978. CrossRef Medline

Batagov AO, Kurochkin IV (2013) Exosomes secreted by human cells transport largely mRNA fragments that are enriched in the $3^{\prime}$-untranslated regions. Biol Direct 8:12. CrossRef Medline

Bellingham SA, Coleman BM, Hill AF (2012a) Small RNA deep sequencing reveals a distinct miRNA signature released in exosomes from prioninfected neuronal cells. Nucleic Acids Res 40:10937-10949. CrossRef Medline

Bellingham SA, Guo BB, Coleman BM, Hill AF (2012b) Exosomes: vehicles for the transfer of toxic proteins associated with neurodegenerative diseases? Front Physiol 3:124. CrossRef Medline

Bobrie A, Colombo M, Raposo G, Théry C (2011) Exosome secretion: molecular mechanisms and roles in immune responses. Traffic 12:16591668. CrossRef Medline

Bronisz A, Wang Y, Nowicki MO, Peruzzi P, Ansari KI, Ogawa D, Balaj L, De Rienzo G, Mineo M, Nakano I, Ostrowski MC, Hochberg F, Weissleder R, Lawler SE, Chiocca EA, Godlewski J (2014) Extracellular vesicles modulate the glioblastoma microenvironment via a tumor suppression signaling network directed by miR-1. Cancer Res 74:738-750. CrossRef Medline

Court FA, Alvarez J (2005) Local regulation of the axonal phenotype, a case of merotrophism. Biol Res 38:365-374. CrossRef Medline

Court FA, Hendriks WT, MacGillavry HD, Alvarez J, van Minnen J (2008) Schwann cell to axon transfer of ribosomes: toward a novel understanding of the role of glia in the nervous system. J Neurosci 28:11024-11029. CrossRef Medline

Court FA, Midha R, Cisterna BA, Grochmal J, Shakhbazau A, Hendriks WT, Van Minnen J (2011) Morphological evidence for a transport of ribosomes from Schwann cells to regenerating axons. Glia 59:1529-1539. CrossRef Medline

D’Asti E, Garnier D, Lee TH, Montermini L, Meehan B, Rak J (2012) Oncogenic extracellular vesicles in brain tumor progression. Front Physiol 3:294. CrossRef Medline

Ehehalt R, Keller P, Haass C, Thiele C, Simons K (2003) Amyloidogenic processing of the Alzheimer beta-amyloid precursor protein depends on lipid rafts. J Cell Biol 160:113-123. CrossRef Medline

El Andaloussi S, Mäger I, Breakefield XO, Wood MJ (2013) Extracellular vesicles: biology and emerging therapeutic opportunities. Nat Rev Drug Discov 12:347-357. CrossRef Medline

Fowler DM, Koulov AV, Alory-Jost C, Marks MS, Balch WE, Kelly JW (2006) Functional amyloid formation within mammalian tissue. PLoS Biol 4:e6. CrossRef Medline

Fröhlich D, Kuo WP, Frühbeis C, Sun JJ, Zehendner CM, Luhmann HJ, Pinto S, Toedling J, Trotter J, Krämer-Albers EM (2014) Multifaceted effects of oligodendroglial exosomes on neurons: impact on neuronal firing rate, signal transduction, and gene regulation. Philos Trans R Soc Lond B Biol Sci 369:pii20130510. CrossRef Medline

Frühbeis C, Fröhlich D, Kuo WP, Krämer-Albers EM (2013a) Extracellular vesicles as mediators of neuron-glia communication. Front Cell Neurosci 7:182. CrossRef Medline

Frühbeis C, Fröhlich D, Kuo WP, Amphornrat J, Thilemann S, Saab AS, Kirchhoff F, Möbius W, Goebbels S, Nave KA, Schneider A, Simons M, Klugmann M, Trotter J, Krämer-Albers EM (2013b) Neurotransmitter- triggered transfer of exosomes mediates oligodendrocyte-neuron communication. PLoS Biol 11:e1001604. CrossRef Medline

Garnier D, Jabado N, Rak J (2013) Extracellular vesicles as prospective carriers of oncogenic protein signatures in adult and paediatric brain tumours. Proteomics 13:1595-1607. CrossRef Medline

Grbovic OM, Mathews PM, Jiang Y, Schmidt SD, Dinakar R, Summers-Terio NB, Ceresa BP, Nixon RA, Cataldo AM (2003) Rab5-stimulated upregulation of the endocytic pathway increases intracellular beta-cleaved amyloid precursor protein carboxyl-terminal fragment levels and Abeta production. J Biol Chem 278:31261-31268. CrossRef Medline

Greenwald J, Riek R (2010) Biology of amyloid: structure, function, and regulation. Structure 18:1244-1260. CrossRef Medline

György B, Hung ME, Breakefield XO, Leonard JN (2014) Therapeutic applications of extracellular vesicles-clinical promise and open questions. Ann Rev Pharmacol Toxicol. Advance online publication. doi:10.1146/ annurev-pharmtox-010814-124630. CrossRef Medline

Haass C, Selkoe DJ (2007) Soluble protein oligomers in neurodegeneration: lessons from the Alzheimer's amyloid beta-peptide. Nat Rev Mol Cell Biol 8:101-112. CrossRef Medline

Hammer ND, Wang X, McGuffie BA, Chapman MR (2008) Amyloids: friend or foe? J Alzheimers Dis 13:407-419. Medline

Harris PC, Torres VE (2014) Genetic mechanisms and signaling pathways in autosomal dominant polycystic kidney disease. J Clin Invest 124:23152324. CrossRef Medline

Hochberg FH, Atai NA, Gonda D, Hughes MS, Mawejje B, Balaj L, Carter RS (2014) Glioma diagnostics and biomarkers: an ongoing challenge in the field of medicine and science. Expert Rev Mol Diagn 14:439-452. CrossRef Medline

Hogan MC, Manganelli L, Woollard JR, Masyuk AI, Masyuk TV, Tammachote R, Huang BQ, Leontovich AA, Beito TG, Madden BJ, Charlesworth MC, Torres VE, LaRusso NF, Harris PC, Ward CJ (2009) Characterization of PKD protein-positive exosome-like vesicles. J Am Soc Nephrol 20:278-288. CrossRef Medline

Hurbain I, Geerts WJ, Boudier T, Marco S, Verkleij AJ, Marks MS, Raposo G (2008) Electron tomography of early melanosomes: implications for melanogenesis and the generation of fibrillar amyloid sheets. Proc Natl Acad Sci U S A 105:19726-19731. CrossRef Medline

Iero M, Valenti R, Huber V, Filipazzi P, Parmiani G, Fais S, Rivoltini L (2008) Tumour-released exosomes and their implications in cancer immunity. Cell Death Diff 15:80-88. CrossRef Medline

Koo EH, Squazzo SL (1994) Evidence that production and release of amyloid beta-protein involves the endocytic pathway. J Biol Chem 269: 17386-17389. Medline

Kummer MP, Maruyama H, Huelsmann C, Baches S, Weggen S, Koo EH (2009) Formation of Pmell7 amyloid is regulated by juxtamembrane metalloproteinase cleavage, and the resulting C-terminal fragment is a substrate for gamma-secretase. J Biol Chem 284:2296-2306. CrossRef Medline

Lai CP, Breakefield XO (2012) Role of exosomes/microvesicles in the nervous system and use in emerging therapies. Front Physiol 3:228. CrossRef Medline

Li CC, Eaton SA, Young PE, Lee M, Shuttleworth R, Humphreys DT, Grau GE, Combes V, Bebawy M, Gong J, Brammah S, Buckland ME, Suter CM (2013) Glioma microvesicles carry selectively packaged coding and noncoding RNAs which alter gene expression in recipient cells. RNA Biol 10:1333-1344. CrossRef Medline

Lopez-Verrilli MA, Court FA (2012) Transfer of vesicles from Schwann cells to axons: a novel mechanism of communication in the peripheral nervous system. Front Physiol 3:205. CrossRef Medline

Lopez-Verrilli MA, Court FA (2013a) Exosomes: mediators of communication in eukaryotes. Biol Res 46:5-11. CrossRef Medline

Lopez-Verrilli MA, Picou F, Court FA (2013b) Schwann cell-derived exosomes enhance axonal regeneration in the peripheral nervous system. Glia 61:1795-1806. CrossRef Medline

Masyuk AI, Huang BQ, Ward CJ, Gradilone SA, Banales JM, Masyuk TV, Radtke B, Splinter PL, LaRusso NF (2010) Biliary exosomes influence cholangiocyte regulatory mechanisms and proliferation through interaction with primary cilia. Am J Physiol Gastrointest Liver Physiol 299: G990-G999. CrossRef Medline

Nave KA (2010) Myelination and support of axonal integrity by glia. Nature 468:244-252. CrossRef Medline

Nolte-'t Hoen EN, Buermans HP, Waasdorp M, Stoorvogel W, Wauben MH, 
't Hoen PA (2012) Deep sequencing of RNA from immune cell-derived vesicles uncovers the selective incorporation of small non-coding RNA biotypes with potential regulatory functions. Nucleic Acids Res 40:92729285. CrossRef Medline

O’Hagan R, Wang J, Barr MM (2014) Mating behavior, male sensory cilia, and polycystins in C. elegans. Semin Cell Dev Biol 33:25-33. CrossRef Medline

Pampliega O, Orhon I, Patel B, Sridhar S, Díaz-Carretero A, Beau I, Codogno P, Satir BH, Satir P, Cuervo AM (2013) Functional interaction between autophagy and ciliogenesis. Nature 502:194-200. CrossRef Medline

Rajendran L, Annaert W (2012) Membrane trafficking pathways in Alzheimer's disease. Traffic 13:759-770. CrossRef Medline

Rajendran L, Honsho M, Zahn TR, Keller P, Geiger KD, Verkade P, Simons K (2006) Alzheimer's disease beta-amyloid peptides are released in association with exosomes. Proc Natl Acad Sci U S A 103:11172-11177. CrossRef Medline

Rajendran L, Schneider A, Schlechtingen G, Weidlich S, Ries J, Braxmeier T, Schwille P, Schulz JB, Schroeder C, Simons M, Jennings G, Knölker HJ, Simons K (2008) Efficient inhibition of the Alzheimer's disease betasecretase by membrane targeting. Science 320:520-523. CrossRef Medline

Rak J (2013) Extracellular vesicles: biomarkers and effectors of the cellular interactome in cancer. Front Pharmacol 4:21. CrossRef Medline

Raposo G, Marks MS (2007) Melanosomes: dark organelles enlighten endosomal membrane transport. Nat Rev Mol Cell Biol 8:786-797. CrossRef Medline

Redzic J, Balaj L, van der Vos K, Breakefield XO (2014a) Extracellular RNA mediates and marks cancer progression. Issue: Exosomes in immunity and cancer-friends or foes? Semin Cancer Biol. 28:14-23, 2014

Redzic JS, Ung TH, Graner MW (2014b) Glioblastoma extracellular vesicles: reservoirs of potential biomarkers. Pharmgenomics Pes Med 7:6577. CrossRef Medline

Rochin L, Hurbain I, Serneels L, Fort C, Watt B, Leblanc P, Marks MS, De Strooper B, Raposo G, van Niel G (2013) BACE2 processes PMEL to form the melanosome amyloid matrix in pigment cells. Proc Natl Acad Sci U S A 110:10658-10663. CrossRef Medline

Schneider A, Rajendran L, Honsho M, Gralle M, Donnert G, Wouters F, Hell SW, Simons M (2008) Flotillin-dependent clustering of the amyloid precursor protein regulates its endocytosis and amyloidogenic processing in neurons. J Neurosci 28:2874-2882. CrossRef Medline

Semmo M, Köttgen M, Hofherr A (2014) The TRPP subfamily and polycystin-1 proteins. Handb Exp Pharmacol 222:675-711. CrossRef Medline

Simons M, Raposo G (2009) Exosomes: vesicular carriers for intercellular communication. Curr Opin Cell Biol 21:575-581. CrossRef Medline

Skog J, Würdinger T, van Rijn S, Meijer DH, Gainche L, Curry WT Jr, Carter BS, Krichevsky AM, Breakefield XO (2008) Glioblastoma microvesicles transport RNA and protein that promote tumor growth and provide diagnostic biomarkers. Nat Cell Biol 10:1470-1476. CrossRef Medline

Stoorvogel W, Kleijmeer MJ, Geuze HJ, Raposo G (2002) The biogenesis and functions of exosomes. Traffic 3:321-330. CrossRef Medline

Takahashi RH, Milner TA, Li F, Nam EE, Edgar MA, Yamaguchi H, Beal MF, $\mathrm{Xu} \mathrm{H}$, Greengard P, Gouras GK (2002) Intraneuronal Alzheimer abeta42 accumulates in multivesicular bodies and is associated with synaptic pathology. Am J Pathol 161:1869-1879. CrossRef Medline

Tanaka Y, Okada Y, Hirokawa N (2005) FGF-induced vesicular release of Sonic hedgehog and retinoic acid in leftward nodal flow is critical for left-right determination. Nature 435:172-177. CrossRef Medline

Theos AC, Truschel ST, Raposo G, Marks MS (2005) The Silver locus product Pmel17/gp100/Silv/ME20: controversial in name and in function. Pigment Cell Res 18:322-336. CrossRef Medline

Theos AC, Truschel ST, Tenza D, Hurbain I, Harper DC, Berson JF, Thomas PC, Raposo G, Marks MS (2006) A lumenal domain-dependent pathway for sorting to intralumenal vesicles of multivesicular endosomes involved in organelle morphogenesis. Dev Cell 10:343-354. CrossRef Medline

Théry C, Ostrowski M, Segura E (2009) Membrane vesicles as conveyors of immune responses. Nat Rev Immunol 9:581-593. CrossRef Medline

Vader P, Breakefield XO, Wood MJ (2014) Extracellular vesicles: emerging targets for cancer therapy. Trends Mol Med 20:385-393. CrossRef Medline

van Niel G, Charrin S, Simoes S, Romao M, Rochin L, Saftig P, Marks MS, Rubinstein E, Raposo G (2011) The tetraspanin CD63 regulates ESCRTindependent and -dependent endosomal sorting during melanogenesis. Dev Cell 21:708-721. CrossRef Medline

Vella LJ, Sharples RA, Nisbet RM, Cappai R, Hill AF (2008) The role of exosomes in the processing of proteins associated with neurodegenerative diseases. Eur Biophys J 37:323-332. CrossRef Medline

Villegas R, Martinez NW, Lillo J, Pihan P, Hernandez D, Twiss JL, Court FA (2014) Calcium release from intra-axonal endoplasmic reticulum leads to axon degeneration through mitochondrial dysfunction. J Neurosci 34: 7179-7189. CrossRef Medline

Wang J, Silva M, Haas LA, Morsci NS, Nguyen KC, Hall DH, Barr MM (2014) C. elegans ciliated sensory neurons release extracellular vesicles that function in animal communication. Curr Biol 24:519-525. CrossRef Medline

Watt B, van Niel G, Raposo G, Marks MS (2013) PMEL: a pigment cellspecific model for functional amyloid formation. Pigment Cell Melanoma Res 26:300-315. CrossRef Medline

Wood CR, Huang K, Diener DR, Rosenbaum JL (2013) The cilium secretes bioactive ectosomes. Curr Biol 23:906-911. CrossRef Medline

Yuan S, Sun Z (2013) Expanding horizons: ciliary proteins reach beyond cilia. Annu Rev Genet 47:353-376. CrossRef Medline 